\title{
Novel Mutation Found in Exon 12 of LAMA-2 Gene in Iranian Congenital Gravismeros in syndrome Patients
} \author{
Mehdi Moradyar ${ }^{5}$ and Seyyed Hassan Tonekaboni ${ }^{6}$ \\ ${ }^{1}$ Islamic Azad University, Iran \\ ${ }^{2}$ National Institute of Genetic Engineering and Biotechnology, Iran \\ ${ }^{3}$ Department of Pediatric Neurology, University of Medical Science, Iran \\ ${ }^{4}$ Pediatric Pathology research center, Shahid Beheshti University of Medical Sciences, Iran \\ ${ }^{5}$ Department of Biotechnology Science and Research Branch, Islamic Azad University, Iran \\ ${ }^{6}$ Pediatrict Neurology research Center SBMU, Iran
}

Negar Khodaeinia ${ }^{1}$, Massoud Houshmand ${ }^{2}$, Elmira Sanjari ${ }^{2}$, Fakhreddin Shariat Madari ${ }^{3}$, Yalda Nilipour ${ }^{4}$

Submission: April 26, 2017; Published: August 11, 2017

*Corresponding author: Massoud Houshmand, National Institute of Genetic Engineering and Biotechnology, Head of the Genetic Diagnostic Lab, Tehran, Iran, Tel: +98-21-44787390; Fax: +98-21-44787399; Email: massoudh@nigeb.ac.ir

\begin{abstract}
Muscular dystrophy (MD) is a group of multiple muscle diseases, which cause severe degeneration and dysfunctions in musculoskeletal system and hamper locomotion like walking or moving. Genetic is main cause of Muscular dystrophies and LAMA-2 is a marker gene for congenital myasthenia disease (CMD). Exon 12 and exon 56 of LAMA-2 gene sequenced in 20 Iranian patients of congenital Gravis myasthenia syndrome. Results presented novel mutation of (c.1798G>A homo p.G600R) in exon 12 in one patient. In exon 56, 10 patients carried benign mutation and none of them carried pathogenic mutation. 8 patients had no mutation in both exons. It seems that pathogen mutations of LAMA-2 gene in Iranian population of CMD are different from other populations.
\end{abstract}

Key words: LAMA-2; Gravis myasthenia syndrome

\section{Introduction}

Muscular dystrophy (MD) is a group of multiple muscle diseases, which affects the musculoskeletal system and hamper locomotion like walking or moving. Muscular dystrophies are characterized by progressive skeletal muscle weakness, defects in muscle proteins, and lead to degeneration and death of muscle cells and tissue in the final stage of disease [1,2]. Genetic is the main reason of almost all Muscular dystrophies but various inheritance patterns revealed in different muscular dystrophies. In addition several mutations in several genes are associated to muscular dystrophies types. Mutations in dystrophin gene are main cause of Duchenne and Becker types and mutations in EMD and LMNA genes are associated with Emery-Dreifuss muscular dystrophy [1]. Diagnosis of muscular dystrophy is based on muscle biopsy, increased creatine phosphokinase (CpK3), electromyography, electrocardiography and genetic tests [3]. Unfortunately still there is no specific treatment for muscular dystrophy but physiotherapy, aerobic exercise, yoga; low intensity catabolic steroids can help to maintain muscle tone. Also diet rich of nutrient supplements such as Vitamin
D3, calcium, whey protein, creatine and glutamine could help to prevent contractures [4]. Laminin, is an extracellular protein, and a component of the basement membrane which is involved in attachment, migration, and organization of cells into tissues during embryonic development by interacting with other extracellular matrix components. Lamin in has three subunits, alpha, beta, and gamma, which are bound to each other by disulfide bonds into a cross-shaped molecule. LAM-2 which is located in 6q22-q23 encodes the alpha 2 chain, which constitutes one of the subunits of laminin 2 (merosin) and laminin 4 (s-merosin). LAMA-2 length is over 260, 000 base pairs which contains 64 exons. Mutations in this gene have been identified as the cause of congenital merosin-deficient muscular dystrophy [5]. Congenital myasthenia syndrome (CMD) is a severe form of congenital muscular disorder and characterized by significant dystrophic changes in skeletal muscles. Mechanisms of the muscle fiber degeneration in CMD are not completely clarified [6]. Several point mutations, deletions and duplications in several exons of LAMA-2 are associated with 
CMD; including exons $12,19,20,37,42$ and 56 , but ariant is mutations in different populations detected in different exons. Population genetic studies in mutations of LAMA-2 could help to find important mutations of LAMA-2 in muscular dystrophy patients in different populations [7,8]. Present study aimed to assess the mutations of exon 12 and exon 56 of LAMA- 2 in Iranian population of congenital Gravis myasthenia syndrome patients (Table 1).

Table 1: primers of exon 12 and exon 56.

\begin{tabular}{|l|l|}
\hline LAMA-2 exon 12 Forward primer & 5'TGATTTAATAGCCCATCT3' \\
\hline LAMA-2 exon 12 Reveres primer & 5'ACATCAGGAAGTAACACG3' \\
\hline LAMA-2 exon 56 Forward primer & 5'TGTATTGAATCAGATGTG3' \\
\hline LAMA-2 exon 56 Reveres primer & 5'GTAGTAGTAATGAGGAGA3' \\
\hline
\end{tabular}

\section{Material and Methods}

\section{Subjects sampling}

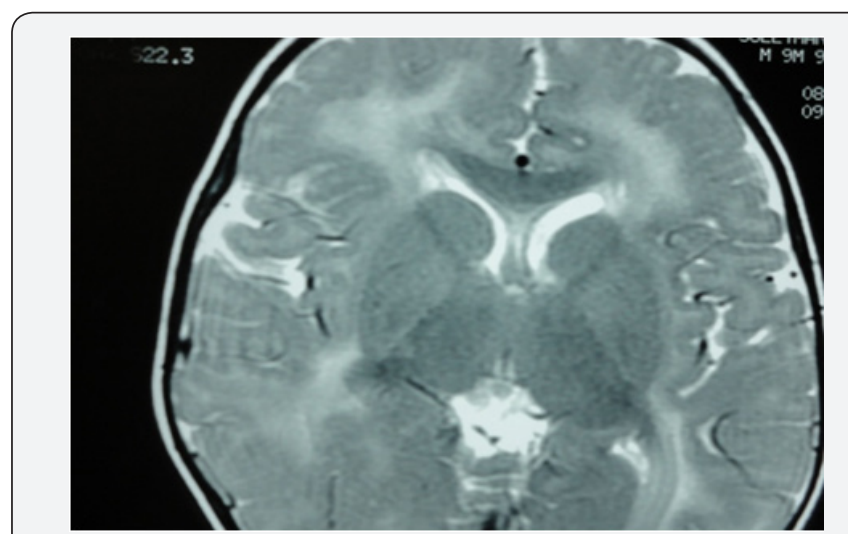

Figure 1: MRI graph of one congenital Gravis myasthenia disease patient: a 10 month old male patient who was born of normal phenotype parents and admitted to neurologic clinic as flopping baby. He had history of hypotonia since birth. A physical examination showed scoliosis and head lag controlling. He couldn't sit with aide and he was alert and oriented, eye movement and popimary reflexes were normal. The patient reflexes were decreased and his sensory and cronial nerve examination unremarked hole. Biochemical parameters including Aldulase and Creatine kinase were abnormal.

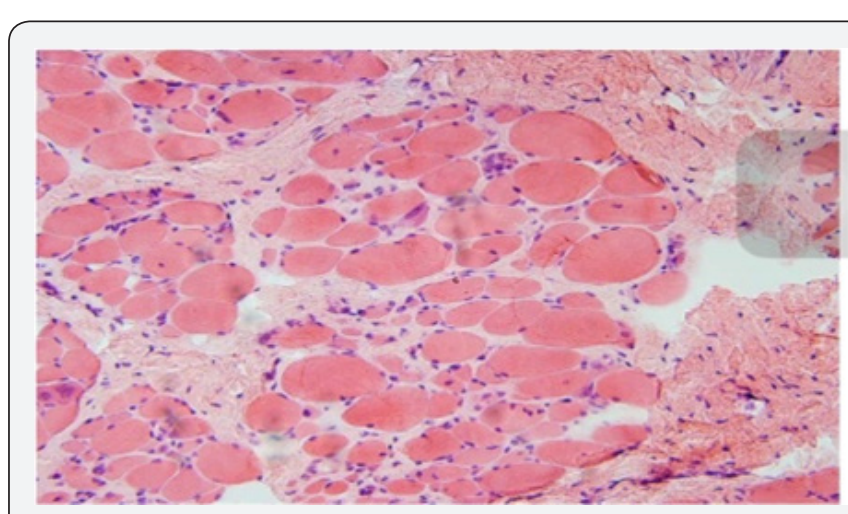

Figure 2: Biopsy of the congenital Gravis myasthenia disease patient reported in Figure 1.

Allsubjects were informed about the experimental process and a written consent was obtained. 20 Iranian patients of congenital Gravis myasthenia syndrome (10 male, 10 female) selected and blood samples collected from patients. MRI graph, pathological biopsy and clinical report of one of the patients presented in (Figures 1 \& 2).

\section{DNA extraction}

DNA from lymphocytesof peripheral blood extracted using Roche Applied Science, DNA Isolation Kit for Mammalian Blood (Cat. No. 11667327 001). Integrity and quality of extracted DNA evaluated by using agrose gel electrophoresis.

\section{PCR amplification}

Primers for two exons of LAMA-2, exon 12 and exon 56 designed by Oligo 7 software and blasted on NCBI. Primers presented in Table 1. Full lengths of two mentioned exons were amplified by PCR using Roche Applied Science, PCR master mix (11636103001).

\section{DNA sequencing}

DNA cycle sequencing performed on automated sequencers ABI 3700 and results checked in NCBI, omim 'polyphenc 'sift exom ariant data bases after using Finch TV software for compare with normal sequence.

\section{Results}

Table 2: Summary of DNA sequencing results.

\begin{tabular}{|c|c|c|}
\hline Patients & Exon 12 & Exon 56 \\
\hline p1 & c.7938 G>A hetero & \\
\hline p.Met 2649 Ile & - & \\
\hline p2 & - & c.1798G $>$ A homo \\
\hline \multicolumn{3}{|l|}{ p.G600R } \\
\hline p3 & c.7938 G>A hetero & \\
\hline p.Met 2649 Ile & - & \\
\hline $\mathrm{p} 4$ & - & - \\
\hline p5 & c.7938 G>A hetero & \\
\hline p.Met 2649 Ile & - & \\
\hline p6 & - & - \\
\hline p7 & - & - \\
\hline p8 & c.7938 G>A hetero & \\
\hline p.Met 2649 Ile A & - & \\
\hline p9 & - & - \\
\hline p10 & Hero & \\
\hline c. $8076+6 \mathrm{G}>\mathrm{A}$ & - & \\
\hline p11 & c.7938 G>A hetero & \\
\hline p.Met 2649 Ile & - & \\
\hline $\mathrm{p} 12$ & c.7938 G>A hetero & \\
\hline p.Met 2649 Ile & c.1856G >A homo & \\
\hline p.R619 H & & \\
\hline
\end{tabular}




\section{International Journal of Cell Science \& Molecular Biology}

\begin{tabular}{|c|c|c|}
\hline $\begin{array}{c}\text { bening } \\
\text { polymorphism }\end{array}$ & \\
\hline p13 & c.7938 G $>$ A hetero & \\
\hline p.Met 2649 Ile & - & \\
\hline p14 & c.7938 G>A hetero & \\
\hline p.Met 2649 Ile & - & \\
\hline p15 & c.7938 G >A hetero & \\
\hline p.Met 2649 Ile & - & \\
\hline p16 & - & c.1856 G $>$ A homo \\
\hline p.R619 H & & \\
\hline polymorphism & & \\
\hline p17 & - & \\
\hline p18 & - & \\
\hline p19 & - & - \\
\hline p20 & - & \\
\hline
\end{tabular}

From 20 patients, results for exon 12 of LAMA-2 gene showed that just 3 patients $(\mathrm{p} 2, \mathrm{p} 12, \mathrm{p} 16)$ had mutation in this exon and just one of them (p2) carried one damage mutation and two other patients had no mutations beyond normal single nucleotide polymorphisms (SNP). Other 17 patients had no mutation in exon 12. For exon 56 results showed 10 patients ( $\mathrm{p} 1$ ,p3,p5,p8,p10,p11,p12,p13,p14,p15) had mutations entirely of heterozygous nature and p10 also carried intronic variations. All of the mutations in exon 56 were being mutations and not related to the disease. 8 patients (p4,p6,p7,p9,p17,p18,p19,p20) had no mutation in neither exons. Summary of results presented in (Table 2).

\section{Discussion}

Muscular dystrophies are multi factorial and complex diseases with several ambiguities about mechanisms of muscle fiber degeneration, neuro degeneration and brain pathological symptoms. Prenatal diagnoses in these diseases are mandatory for prevention. Achievement to an accurate and chip prenatal diagnostic protocol for muscular dystrophies needs to find strong genetic markers, including population specific markers. Several previous reports indicated LAMA-2 as marker gene for Merosindeficient congenital muscular dystrophy but studies showed that different population have different pathogenic mutations in this gene [9]. (c.1798G>A homo p.G600R) which found in p2 patient have been reported in 4 patients of 200 CMD patients in European population as germ line mutation [9] and another study in 2013 which assessed CMD patients of Arab tribe found it as probably damage mutation. Based on results which is first report about exon 12 of LAMA-2in Iranian CMD patients, this mutation could be a new founded pathogen mutation in middle east population. (c.1856 G>A homo p.R619 H) mutation previously considered as single nucleotide polymorphism in Caucasians [10] and as bening mutation in European population [11]. Present study is in accordance with the previous investigations. Other pathogen mutations, reported in exon 12 in previous reports have not been observed in Iranian population. In the Iranian population, the exon 56 mutations are of benign nature.

\section{Conclusion}

The Most significant finding in the present study is associated with the absence of mutations in both exons in 8 patient. This leads us to search other exons to find probable novel genetic markers for CMD patients in Iranian population. Further studies in bigger sample size by whole LAMA-2 exons sequencing along with deep sequencing of promoter, 3' and 5' UTRs and intronic regions and gene expression assessment may clarify the role of LAMA-2 mutations in different types of muscular dystrophies in different populations.

\section{References}

1. Emery AE (2002) The muscular dystrophies. The Lancet 359(9307): 687-695.

2. Fauci, Anthony S (2008) Harrison's principles of internal medicine. Medical Publishing Division, McGraw-Hill, USA.

3. Bushby K, Finkel R, Birnkrant DJ, Case LE, Clemens PR, et al. (2010) Diagnosis and management of Duchenne muscular dystrophy, part 1: diagnosis, and pharmacological and psychosocial management. The Lancet Neurology 9(1): 77-93.

4. Pedretti LW, Early MB (2001) Occupational therapy: Practice skills for physical dysfunction: Mosby Ann Arbor, USA.

5. Geranmayeh F, Clement E, Feng LH, Sewry C, Pagan J (2010) Genotypephenotype correlation in a large population of muscular dystrophy patients with LAMA2 mutations. Neuromuscular Disorders 20(4): 241-250.

6. Hayashi YK, Tezak Z, Momoi T, Nonaka I, Garcia CA, et al. (2001) Massive muscle cell degeneration in the early stage of merosindeficient congenital muscular dystrophy. Neuromuscular Disorders 11(4): 350-359.

7. Di B, Claudia P, Daniela B, Paolo M, Isabella P, et al. (2005) LAMA2 gene analysis in congenital muscular dystrophy: new mutations, prenatal diagnosis, and founder effect. Archives of neurology 62(10): 15821586.

8. Oliveira J, Gonçalves A, Oliveira ME, Fineza I, Pavanello R, et al. (2014) Reviewing large LAMA2 deletions and duplications in congenital muscular dystrophy patients. Journal of Neuromuscular Diseases 1(2): 169-179.

9. Guicheney P, Vignier N, Zhang Xu, He Yi, Cruaud C, et al. (1998) PCR based mutation screening of the laminin alpha2 chain gene (LAMA2): application to prenatal diagnosis and search for founder effects in congenital muscular dystrophy. Journal of medical genetics 35(3): 211-217.

10. Pegoraro E, Marks, Garcia H, Crawford CA, Mancias T, et al. (1998) Laminin $\alpha 2$ muscular dystrophy Genotype/phenotype studies of 22 patients. Neurology 51(1): 101-110.

11. Zivana T, Paola P, Marco B, Alessandra M, Joseph D, et al. (2003) Clinical and molecular study in congenital muscular dystrophy with partial laminin $\alpha 2$ (LAMA2) deficiency. Human mutation 21(2): 103-111. 
(C) This work is licensed under Creative Commons Attribution 4.0 Licens
Your next submission with Juniper Publishers will reach you the below assets

- Quality Editorial service

- Swift Peer Review

- Reprints availability

- E-prints Service

- Manuscript Podcast for convenient understanding

- Global attainment for your research

- Manuscript accessibility in different formats ( Pdf, E-pub, Full Text, Audio)

- Unceasing customer service

Track the below URL for one-step submission https://juniperpublishers.com/online-submission.php 